\title{
MEMAHAMI KOMUNIKASI ANTAR BUDAYA DALAM LAYANAN KONSELING KELOMPOK
}

\author{
Yuwinda Ardila \\ Pascasarjana Universitas Negeri Semarang \\ Email: ardilayuwinda@students.unnes.ac.id
}

\begin{abstract}
Abstrak
Dalam pelaksanaan layanan konseling lintas budaya, pemahaman terhadap komunikasi antar budaya menjadi amat krusial mengingat komunikasi sebagai alat utama dalam layanan konseling. Konseling lintas budaya dilakukan dalam latar belakang budaya yang berbeda antara konselor dengan konseli, dan antara konseli dalam kelompok. Latar belakang perbedaan budaya memberikan perilaku bermasalah dan cara penyesuaian yang berbeda pada tiap konseli dalam kelompok. Beberapa hal yang mempengaruhi komunikasi antar budaya diantaranya yaitu pendekatan komunikasi, hambatan komunikasi dan penyebab terganggunya komunikasi antar budaya.

Tujuan dari penelitian ini adalah untuk memahami lebih lanjut komunikasi antar budaya serta beberapa hal yang mempengaruhi komunikasi dalam konteks konseling kelompok. Agar proses konseling menjadi efektif, konselor diharuskan memiliki kepekaan budaya dan melepaskan diri dari bias budaya, mampu memahami dan menghargai serta memiliki keterampilan yang responsif secara budaya. Pada saat konseling, konselor tidak hanya berurusan dengan budaya konseli tetapi juga sebaliknya, maka konselor diharapkan mampu membuat konseli paham atas budaya konselor itu sendiri untuk menghilangkan adanya bias budaya dalam komunikasi konseling.
\end{abstract}

Kata kunci: konseling lintas budaya, komunikasi antarbudaya, efektivitas proses konseling kelompok.

\section{PENDAHULUAN}

Keberagaman suku, budaya, ras, warna kulit dan bahasa bisa menjadi hambatan dalam pelaksanaan konseling apabila konselor tidak mempunyai kemampuan yang cukup dalam mengolah dan mengendalikan layanan untuk konseli dengan latar belakang berbeda. Kendala dalam berbahasa sering menjadikan proses konseling tidak terlaksana dengan efektif karena komunikasi merupakan media utama dalam melakukan layanan konseling baik individu maupun kelompok. Konseling kelompok yang memanfaatkan kohesivitas sebagai kekuatan dalam kelompok akan terbentuk dengan baik melalui komunikasi yang efektif, dengan kohesivitas para anggota kelompok akan saling menerima, mendukung, serta tercipta kebermaknaan dalam konseling kelompok. 

Keterampilan konseling
hampir seluruhnya melibatkan
keterampilan komunikasi konselor.
Hal ini di sesuai dengan yang
dinyatakan oleh Geldard \& Geldard (2005) bahwa dalam penyelenggaraan praktik layanan konseling, konselor mengandalkan beberapa keterampilan yang salah satunya adalah keterampilan komunikasi sebagai keterampilan mikro konseling. NelsonJones (2008) menyebutkan bahwa keterampilan utama konseling ada dua kategori: 1) keterampilan komunikasi dan bertindak, dan 2) keterampilan pikiran. Keterampilan komunikasi dan bertindak melibatkan perilaku eksternal, dan keterampilan pikiran melibatkan perilaku internal konselor. Dapat dipahami bahwa keterampilan utama yang harus dikuasai konselor dalam penyelenggaraan praktik konseling kelompok adalah keterampilan komunikasi.

Pelaksanaan konseling

kelompok yang diikuti oleh beberapa konseli dengan latar belakang yang berbeda, sangat memungkinkan terjadinya bias-bias budaya sehingga dalam pelaksanaanya konselor akan menjumpai beberapa perbedaan budaya. Perbedaan budaya ini dapat menjadi penghalang keefektifan konseling kelompok jika konselor tidak kompeten dalam memahami keterampilan komunikasi antar budaya.

Artikel ini membahas tentang variasi budaya konseli, perbedaan budaya dalam konseling kelompok, komunikasi antar budaya dan kompetensi komunikasi konselor. Tujuan pembahasan artikel secara umum adalah menyajikan wawasan tentang keefektifan konseling kelompok dengan memahami komunikasi antar budaya. Secara khusus, artikel ini sebagai upaya menstimulasi pada konselor serta calon konselor untuk mampu memahami dan menguasai keterampilan komunikasi yang diperlukan agar dapat menyelenggarakan konseling kelompok secara efektif dan efisien.

\section{METODE}

Metode yang digunakan dalam menjawab pertanyaan serta mencapai tujuan dari pembahasan artikel adalah dengan study literasi/kajian pustaka. Pustaka yang menjadi rujukan pembahasan dan pencapaian tujuan penulisan artikel adalah terkait dengan konseling lintas budaya, komunikasi antarbudaya, efektivitas proses konseling kelompok. Literasi yang digunakan dan dirujuk sebagai analisa dan pembahasan tema/topik adalah bersumber dari buku, jurnal/artikel, manuskrip dan beberapa regulasi yang terkait dengan topik pembahasan.

\section{HASIL DAN PEMBAHASAN}

Setiap manusia adalah makhluk yang dibentuk berdasarkan budaya, tidak bisa dipungkiri bahwa pemikiran, sikap dan sifat adalah hasil dari budaya yang diperoleh. Maka konselor dituntut untuk mampu memahami ragam budaya konseli. Hal ini sesuai dengan pernyataan oleh Suhartiwi dan Musifuddin (2013), bahwa seorang konselor lintas budaya tidak hanya membawa pemahaman dan stereotipnya sendiri dalam pelayanan konseling lintas budaya, karena konseli yang akan diberikan 
layanan konseling juga besar dan tumbuh dalam kultur yang bervariatif. Dari pendapat tersebut bisa dikatakan bahwa konselor yang menyelenggarakan praktik konseling multikultural memiliki tanggungjawab dan dedikasi yang tinggi pada profesinya dalam melayanai konseli sesuai dengan perbedaan karakteristik yang dimiliki oleh masing-masing konseli dengan variasi pembentukan budaya.

\section{a. Variasi Budaya Konseli}

Variasi budaya sebagai identitas menjadi hal penting untuk dipahami dalam pelaksanaan konseling. Penelitian yang dilakukan oleh Fandrem (2015) menunjukkan bahwa norma dan nilai budaya dapat memengaruhi tampilan perilaku sosial remaja dalam interaksi teman sebaya dan pertemanan, dan juga fitur struktural dan fungsional dari persahabatan dan organisasi kelompok sebaya. Berdasarkan ketidakkonsistenan hasil penelitian, ada kebutuhan untuk menekankan bahwa makro, sosial (misalnya, kelas, agama, dll.), faktor ekonomi dan individu juga perlu diperhitungkan ketika mempelajari hubungan remaja dan pertemanan. Dengan demikian, faktor-faktor dalam budaya harus mendapat perhatian yang lebih besar.

Studi lain oleh Busch (2018) memberikan wawasan baru tentang bagaimana variasi dalam keyakinan budaya, pengalaman di dunia secara alami, dan pengalaman dengan pendidikan formal dapat membentuk perkembangan penalaran ekologi masyarakat. Data akhir yang disajikan tentang bagaimana sebab keragaman populasi tentang ekologi mengungkapkan fleksibilitas dalam pengembangan pengetahuan ekologi masyarakat.

Berdasarkan hasil studi yang telah dilakukan mengenai variasi budaya dalam lingkup masyarakat secara umum, maka memahami variasi budaya dalam komunikasi konseling menjadikan konselor mampu memahami latar belakang, memahami bahasa tubuh dan memahami perilaku sosial yang dimiliki para konseli dalam konseling kelompok. Hal ini menjadikan konselor lebih peka dalam memahami apa yang disampaikan dan apa yang diinginkan konseli dari pelayanan yang dilaksanakan. Sikap responsif konseli dalam kelompok juga sangat bergantung pada pemahaman konselor atas apa yang mereka sampaikan. Penerimaan positif dari sudut pandang yang berbeda dapat terjalin dalam konteks budaya yang bervariasi.

\section{b. Perbedaan Budaya Dalam Konseling Kelompok}

Sejak dahulu, hidup berkelompok akan lebih baik daripada hidup sendiri. Ini adalah fakta bahwa manusia sebagai makhluk sosial dan selalu berkelompok. Kelompok akan menghasilkan kekuatan untuk hasil kerja yang lebih efesien. Sama halnya dengan konseling yang terkadang akan lebih produktif dengan adanya kohesivitas dalam kelompok, namun berkelompok juga memiliki sisi negatif yang tidak bisa dihindari. Sisi negatif dari berkelompok seringnya terjadi karena gesekan dari perbedaan antar individu; konflik dan disorganisasi. Perbedaan dalam kelompok konseling seharusnya dapat menjadi pendorong kohesivitas jika 
konselor memahami keterampilan komunikasi dengan baik.

Menurut Pedersen (1991), terdapat tiga elemen dalam konseling lintas budaya, yaitu: (1) Konselor dan konseli berasal dari latar belakang budaya yang berbeda, dan melakukan konseling dalam latar belakang budaya (di tempat konseli); (2) Konselor dan konseli berasal dari latar belakang budaya yang berbeda, dan melakukan konseling dalam latar belakang budaya (di tempat konselor); (3) Konselor dan konseli berasal dari latar belakang budaya yang berbeda, dan melakukan konseling di tempat yang berbeda.

Keberhasilan atas pelaksanaan konseling multikultural dengan format kelompok, dapat dilihat melalui beberapa faktor, salah satunya komunikasi efektif. Perbedaan budaya yang terjadi bukanlah halangan efektifitas ketika konselor dan konseli memandang dari arah yang positif, karena kekuatan kelompok dibangun atas perbedaan yang saling melengkapi. Hal ini sejalan dengan Triningtyas (2016) dalam studinya menyimpulkan keefektifan suatu konseling bergantung pada banyak faktor, salah satunya adalah hubungan satu sama lain, dan saling mengerti antara konselor dan klien. Hubungan ini akan lebih mudah tercapai apabila konselor dan klien berasal dari latar belakang budaya yang sama. Perbedaan antara konselor dan klien hendaknya tidak berpengaruh negatif terhadap proses konseling. Konselor yang peduli akan kemaslahatan klien akan memenuhi beberapa aspek tertentu termasuk pada perhatian akan perbedaan budaya. Penerapan konseling

multikultural mengharuskan konselor peka dan tanggap terhadap budaya, keragaman budaya dan adanya perbedaan budaya antara konselor dengan konseli.

\section{c. Komunikasi Antar Budaya}

Andrea L. Rich dan Dennis M. Ogawa menyatakan bahwa "Komunikasi antar budaya adalah komunikasi antara orang-orang yang berbeda kebudayaan, misalnya antar suku bangsa, antar etnik, ras dan antar kelas sosial" (Hadiono, 2016). Dengan kata lain komunikasi antar budaya akan terjadi jika seseorang berinteraksi dengan orang lain yang memiliki suku, etnik, ras dan kelas sosial yang berbeda dengan dirinya. Budaya yang dimiliki seseorang akan mempengaruhi komunikasi verbal dan nonverbal yang ia tunjukkan.

Penelitian telah membuktikan bahwa sebagian besar pesan yang terjadi dalam komunikasi disampaikan secara nonverbal; sehingga saluran nonverbal sebenarnya lebih penting dalam memahami makna dan terutama keadaan emosional dari pembicara (Friedman, 1978; Sue \& Sue, 2008). Namun penelitian lain juga menunjukkan bahwa kebanyakan orang secara sadar memperhatikan bahasa verbal, bukan perilaku nonverbal, ketika berinteraksi dengan dan menilai orang lain (O'Sullivan, Ekman, Friesen, \& Scherer , 1985; Sue \& Sue, 2008). Pengaruh budaya pada komunikasi nonverbal sangat penting untuk diperhatikan sebagai isyarat dalam komunikasi. Dikutip dari Matsumoto (2013) bahwa budaya sangat mempengaruhi komunikasi nonverbal, seperti: (1) gestur yang 
biasanya digunakan untuk memberi penegasan terhadap apa yang disampaikan secara verbal; (2) tatapan, sering digunakan sebagai tanda penghargaan nonverbal; (3) suara, menyampaikan banyak pesan yang berbeda; (4) ruang antarpribadi dan sentuhan (proxemik), untuk menyampaikan makna verbal tanpa kata-kata sebagai isyarat simbolik atau lambang.

Mastumoto (2013) juga menjelaskan akuisi budaya secara bahasa (verbal) dapat mempengaruhi penguasaan bahasa dari tahap yang sangat awal, membantu pembentukan fonem dan morfem bahasa serta penciptaan kata-kata. Budaya memberikan aturan-aturan dengan kata-kata apa yang dikatakan (fonologi), dan dirangkai untuk membentuk pernyataan yang bermakna (sintaksis dan tata bahasa). Budaya juga menyediakan aturan yang dengannya makna berasal dari kata-kata dan pernyataan (semantik), kemudian aturan yang digunakan bahasa dalam konteks sosial yang berbeda (pragmatik).

Dari penjelasan yang telah dipaparkan di atas, dapat diketahui betapa pemahaman komunikasi antar budaya sangat dibutuhkan konselor. Budaya manusia adalah makna unik dan sistem informasi dari hasil lintas generasi. Semua konseli memiliki budaya berbeda-beda yang mengakuisi bahasa verbal dan nonverbal yang unik pada tiap diri mereka. Keefektifan konseling kelompok terjadi tanpa gesekan bias budaya ketika konselor mampu memimpin kelompok konseling melalui pemahaman dan pemberian feedback pada komunikasi antar budaya dengan tepat.

\section{d. Kompetensi Komunikasi Konselor}

Untuk menciptakan konseling yang mampu menjangkau perbedaan latar belakang (ras, budaya, etnis, bahasa dan warna kulit) konselor harus mampu meningkatkan kompetensi yang dimiliki. Termasuk di dalamnya adalah kemampuan berbahasa dan berkomunikasi dengan para konseli yang sedang diberikan bantuan. Lui \& Pope Davis (2005) menyebutkan konseling dan psikoterapi dapat dipandang secara sah sebagai proses interaksi, komunikasi, dan pengaruh sosial terpusat.

Agar konseling kelompok yang efektif dapat terjadi, konselor dan konseli harus dapat mengirim dan menerima pesan verbal maupun nonverbal dengan tepat dan akurat. Sementara gangguan dalam komunikasi sering terjadi antara orang-orang yang berbagi budaya yang sama, masalah menjadi semakin buruk antara orang-orang dari latar belakang ras atau etnis yang berbeda. Banyak ahli kesehatan mental telah mencatat bahwa faktor ras atau etnis dapat bertindak sebagai penghalang terapi/konseling dengan menurunkan pengaruh sosial (Sue \& Sue, 2008). Kesalahpahaman yang muncul dari variasi budaya dalam komunikasi dapat menyebabkan alienasi atau ketidakmampuan untuk mengembangkan kepercayaan dan hubungan. Bentrokan budaya sering dapat terjadi antara nilai-nilai konseling dan psikoterapi dan nilainilai kelompok budaya yang beragam. 
Gaya komunikasi dalam konseling merupakan aspek penting untuk strategi intervensi budaya yang tepat. Dipahami bahwa kebanyakan konselor tampak lebih peduli dengan keakuratan komunikasi (sampai ke inti masalah) daripada dengan apakah komunikasi itu tepat. Ketika mengacu pada gaya komunikasi, berarti membahas faktor-faktor yang melampaui isi dari apa yang dikatakan. Beberapa ahli komunikasi percaya bahwa hanya $30 \%$ hingga $40 \%$ dari apa yang dikomunikasikan secara lisan adalah verbal (Sue \& Sue, 2008:160). Dengan kata lain apa yang seorang katakan dan lakukan dapat diperkuat oleh bahasa nonverbal yang seorang tunjukkan, seperti isyarat, nada, postur bahkan tingkat kontak mata pun dapat meninggalkan isi pesan yang tersirat.

Gaya komunikasi memiliki dampak yang sangat besar pada pertemuan tatap muka antara konselor dengan konseli yang akan menentukan apakah layanan konseling kelompok akan berlanjut dengan tujuan yang diinginkan atau berakhir dengan ketidaksediaan konseli untuk melanjutkan layanan. Pemahaman konselor dalam komunikasi antar budaya baik secara verbal dan nonverbal sangat mempengaruhi kesediaan konseli untuk mengikuti layanan hingga akhir secara sukarela, sehingga kompetensi komunikasi konselor harus terus dilatih dan diperbaharui sebagai kategori utama dalam keterampilan konseling.

\section{KESIMPULAN}

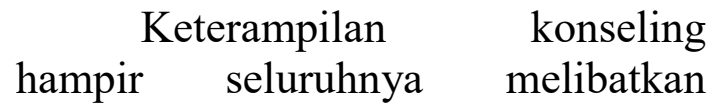

keterampilan komunikasi konselor. Pelaksanaan konseling kelompok yang diikuti oleh beberapa konseli dengan latar belakang yang berbeda, sangat memungkinkan terjadinya bias-bias budaya. Perbedaan budaya dapat menjadi penghalang keefektifan konseling kelompok, oleh karena itu konselor diharapkan kompeten dalam memahami keterampilan komunikasi antar budaya sebagai aspek utama dalam melakukan layanan konseling multikultural.

Memahami komunikasi antar budaya dengan baik adalah usaha besar dalam mendorong terciptanya konseling multikultural yang efektif baik dalam format kelompok maupun format individu. Dengan memiliki pemahaman yang baik terhadap komunikasi antar budaya, konselor diharapkan mampu menjadikan perbedaan budaya sebagai batu loncatan munculnya kohesivitas dalam pelaksanaan konseling multikultural dengan format kelompok. Dengan demikian tujuan layanan konseling kelompok tercapai dengan efektif tanpa adanya gesekan bias budaya.

\section{REFERENSI}

Busch, Justin T. A., et al. (2017). Cross-Cultural Variation In The Development of Folk Ecological Reasoning. Department of Psychology. Manuskrip. (diakses 29 November 2018).

Fandrem, Hildegunn. (2015). Friendship During Adolescence and Cultural Variations. International Encyclopedia of the Social \& 
Behavioral Sciences, 2nd edition. Volume 9.

Geldard, K., \& Geldard, D. (2005). Practical Counselling Skills: An Integrative Approach. Palgrave Macmillan.

Hadiono, Abdi Puji. (2016). Komunikasi Antar Budaya (Kajian Tentang Komunikasi Antar Budaya di Pondok Pesantren Darussalam Blokagung Banyuwangi). Jurnal Darussalam: Jurnal Pendidikan, Komunikasi dan PemikiranHukum Islam. Vol.VIII, No 1: 136-159. September 2016. ISSN: 19784767.

Liu, W. M., \& Pope-Davis, D. B. (2005). The working alliance, therapy ruptures and impasses, and counseling competence: Implications for counselor training and education. In R. T. Carter (Ed.), Handbook of racialcultural psychology and counseling (pp. 148-167). Hoboken, NJ: Wiley.

Matsumono, David.m \& Juang, Linda. (2013). Culture and Psychology (5th edition). Belmonth, CA: Wadsworth Cengange Learning.

Nelson-Jones, R. (2008). Introduction to Counselling Skills: Text and Activities. Sage.

Pedersen. (1991). Counseling Across Cultures. East-West Center Book: University Press of Hawai.

Sue, D.W., \& Sue, D. (2008). Counseling the Culturally: Diverse Theory and Practce (5th Ed). New jersey. JhonWiley \& Sons, Inc.

Suhartiwi \& Musifuddin. (2013). Modus dan Format Pelaksanaan Pelayanan Konseling dalam Memahami Klien Lintas Budaya. Jurnal Konseling dan Pendidikan. Volume 1 Nomor 1, Februari 2013, Hlm 73-82. Indonesian Institute for Counseling and Education (IICE) Multikarya Kons.

Triningtyas, Diana Ariswanti. (2016). The Roles Of Counselor In Multicultural Community. Proceedings International Seminar FoE (Faculty of Education). Vol. 1 Mei 2016. 